\title{
Coral reef ecosystems in the South China Sea as a source of atmospheric $\mathrm{CO}_{2}$ in summer
}

\author{
YAN HongQiang ${ }^{1,2}$, YU KeFu ${ }^{1,2^{*}}$, SHI Qi ${ }^{1,2}$, TAN YeHui ${ }^{1,2}$, ZHANG HuiLing $^{1,2}$, \\ ZHAO MeiXia $^{1,2}$, LI Shu ${ }^{1,2}$, CHEN TianRan ${ }^{1,2}$, HUANG LingYing ${ }^{1,2}$ \& WANG PinXian ${ }^{3}$ \\ ${ }^{1}$ CAS Key Laboratory of Marginal Sea Geology, Guangzhou 510301, China; \\ ${ }^{2}$ South China Sea Institute of Oceanology, Chinese Academy of Sciences, Guangzhou 510301, China; \\ ${ }^{3}$ State Key Laboratory of Marine Geology, Tongji University, Shanghai 200092, China
}

Received May 5, 2010; accepted November 25, 2010

\begin{abstract}
Field measurements of air-sea $\mathrm{CO}_{2}$ exchange in three coral reef areas of the South China Sea (i.e. the Yongshu Reef atoll of the Nansha Islands, southern South China Sea (SCS); Yongxing Island of Xisha Islands, north-central SCS; and Luhuitou Fringing Reef in Sanya of Hainan Island, northern SCS) during the summers of 2008 and 2009 revealed that both air and surface seawater partial pressures of $\mathrm{CO}_{2}\left(p \mathrm{CO}_{2}\right)$ showed regular diurnal cycles. Minimum values occurred in the evening and maximum values in the morning. Air $p \mathrm{CO}_{2}$ in each of the three study areas showed small diurnal variations, while large diurnal variations were observed in seawater $p \mathrm{CO}_{2}$. The diurnal variation amplitude of seawater $p \mathrm{CO}_{2}$ was $\sim 70 \mu \mathrm{mol} \mathrm{mol}{ }^{-1}$ at the Yongshu Reef lagoon, 420-619 $\mu \mathrm{mol} \mathrm{mol}^{-1}$ on the Yongxing Island reef flat, and 264-579 $\mu \mathrm{mol} \mathrm{mol}^{-1}$ on the reef flat of the Luhuitou Fringing Reef, and 324-492 $\mathrm{mol} \mathrm{mol}^{-1}$ in an adjacent area just outside of this fringing reef. With respect to spatial relations, there were large differences in air-sea $\mathrm{CO}_{2}$ flux across the South China Sea (e.g. $\sim 0.4 \mathrm{mmol} \mathrm{CO}_{2} \mathrm{~m}^{-2} \mathrm{~d}^{-1}$ at Yongshu Reef, $\sim 4.7 \mathrm{mmol} \mathrm{CO}_{2} \mathrm{~m}^{-2} \mathrm{~d}^{-1}$ at Yongxing Island, and $\sim 9.8 \mathrm{mmol} \mathrm{CO}_{2} \mathrm{~m}^{-2} \mathrm{~d}^{-1}$ at Luhuitou Fringing Reef). However, these positive values suggest that coral reef ecosystems of the SCS may be a net source of $\mathrm{CO}_{2}$ to the atmosphere. Additional analyses indicated that diurnal variations of surface seawater $p \mathrm{CO}_{2}$ in the shallow water reef flat are controlled mainly by biological metabolic processes, while those of deeper water lagoons and outer reef areas are regulated by both biological metabolism and hydrodynamic factors. Unlike the open ocean, inorganic metabolism plays a significant role in influencing seawater $p \mathrm{CO}_{2}$ variations in coral reef ecosystems.
\end{abstract}

coral reefs, $p \mathrm{CO}_{2}$, carbon cycle, summer, South China Sea

Citation: Yan H Q, Yu K F, Shi Q, et al. Coral reef ecosystems in the South China Sea as a source of atmospheric $\mathrm{CO}_{2}$ in summer. Chinese Sci Bull, 2011, 56: 676-684, doi: 10.1007/s11434-011-4372-8

Both the 1997 Kyoto Protocol and 2009 United Nations Climate Change Conference (Copenhagen) recognized the potential role of $\mathrm{CO}_{2}$ in contributing to global warming. Thus, a reduction in at least the anthropogenic component of $\mathrm{CO}_{2}$ emissions may assist in reducing the degree of possible future warming. However, a more comprehensive understanding of natural processes of absorption and emission of atmospheric $\mathrm{CO}_{2}$ is critical to identify its role in contributing to global warming. Widely-distributed coral reefs in

*Corresponding author (email: kefuyu@ @scsio.ac.cn) tropical oceans have long played an important role in the global carbon cycle [1]. For example, the sudden increase in atmospheric $\mathrm{CO}_{2}\left(\sim 80 \mu \mathrm{mol} \mathrm{mol}{ }^{-1}\right)$ during retreat of the Wisconsinan glaciers (ca.14 ka) has been hypothesized to have been the result of variations of coral reef carbonate sedimentation rates [2-4]. The contribution of coral reefs to the carbon cycle is driven mainly by organic carbon metabolism (photosynthetic fixation and respiration/degradation) and inorganic carbon metabolism (precipitation and dissolution of calcium carbonate); inorganic carbon metabolism also may play a significant role [5-8]. Importantly, 
coral reefs contribute 7\%-15\% [6] of global $\mathrm{CaCO}_{3}$ production. In recent years, several studies have examined the role of coral reefs and their contribution to atmospheric $\mathrm{CO}_{2}$ by measuring seawater $p \mathrm{CO}_{2}$ and atmospheric $p \mathrm{CO}_{2}$ in coral reefs [6-11]. They indicate that although coral reefs are mostly net sources [7-16] of atmospheric $\mathrm{CO}_{2}$, they may also act as sinks $[6,17,18]$ for atmospheric $\mathrm{CO}_{2}$. Suzuki et al. [6] suggested that the contribution of coral reefs to atmospheric $\mathrm{CO}_{2}$ is largely dependent on their topographic and oceanographic settings. Reefs may act as a net source of $\mathrm{CO}_{2}$ if they are dominated by corals, but may take up atmospheric $\mathrm{CO}_{2}$ and act as a sink to the atmosphere if they are dominated by microalgae.

Coral reefs are widely distributed across the South China Sea (SCS), covering the areas from Zenmuansha $\left(\sim 4^{\circ} \mathrm{N}\right)$ in the south, to Leizhou Peninsula, Weizhou Island $\left(\sim 20^{\circ}-21^{\circ} \mathrm{N}\right)$ and Hengchun Peninsula $\left(\sim 24^{\circ} \mathrm{N}\right)$ in the north. The SCS is dominated by fringing reefs, platform reefs (with sand cays) and atolls. The estimated total area of modern coral reefs in the SCS is about $8000 \mathrm{~km}^{2}$ [19]. However, little information is available on the contribution of coral reefs in the SCS to global atmospheric $\mathrm{CO}_{2}$. After a brief investigation at Yongxing Island, in the Xisha Islands, in the spring of 2006, Dai et al. [20] found that surface seawater $p \mathrm{CO}_{2}$ shows significant regular diurnal variations, and that the studied area was a minor source of atmospheric $\mathrm{CO}_{2}$. In order to fully understand the relationship between SCS coral reefs and atmospheric $\mathrm{CO}_{2}$, we carried out detailed measurements of air-sea $\mathrm{CO}_{2}$ exchange at Yongshu Reef (atoll), Nansha Islands, southern SCS; Yongxing Reef (platform reef with a sand cay), Xisha Islands, north-central SCS; and Luhuitou Fringing Reef at Sanya of Hainan Island, northern SCS. Thus, we were able to sample across the three major reef types of the SCS.

\section{Geography and natural environment of the studied coral reefs}

Yongshu Reef $\left(9.52^{\circ}-9.68^{\circ} \mathrm{N}, 112.88^{\circ}-113.06^{\circ} \mathrm{E}\right.$, Figure 1) is located in the Nansha Islands. The reef is an open spindle-shaped atoll, about $25 \mathrm{~km}$ long in the NEE-SWW direction and $6 \mathrm{~km}$ wide in the NW-SE direction (with a total area ca. $110 \mathrm{~km}^{2}$ ). Six basic biogeomorphologic units can be identified in the Yongshu Reef: the reef front slope, outer reef flat, reef ridge, inner reef flat, lagoon slope and lagoon [21]. Since Yongshu Reef is located $>500 \mathrm{~km}$ away from the mainland, it is relatively undisturbed by human activities. An ecological survey carried out in 2006 at Yongshu Reef suggested that the living coral cover was $\sim 60 \%$. The lagoon of Yongshu Reef was selected for this investigation, because its coral atolls are among the most widespread reefs in the Nansha Islands, and its lagoons make up $~ 82 \%$ of the modern atoll systems in the broader Nansha area [19]. Instrumental data from the Yongshu Reef Observatory indi- cate that mean annual sea surface temperature is $28.6^{\circ} \mathrm{C}$. The surface salinity in this area ranges from 33.0 to 33.5 , with monthly variability of 1.0. From June to September, the area is under the influence of southwest monsoons, and has an average wind speed of $6.5 \mathrm{~m} \mathrm{~s}^{-1}$. From November to April, the area is affected by northeast monsoons, with an average wind speed of $8.0 \mathrm{~m} \mathrm{~s}^{-1}$ [22].

Yongxing Island $\left(16.84^{\circ} \mathrm{N}, 112.34^{\circ} \mathrm{E}\right.$, Figure 1) is the largest island of the Xisha Islands, and is located in the north-central SCS. Five geomorphological zones are recognized around Yongxing Island: reef front slope, reef flat, sandy beach, sand bank, sand sheet and low-lying dried lagoon with beach-rock development on the northwest beach [23]. The reef flat is, on average, 400 to $800 \mathrm{~m}$ wide (but extending to as wide as $1500 \mathrm{~m}$ ), and is the major geomorphological zone of Yongxing Island. A survey carried out in 2002 suggested that the coral cover ranged from $42.1 \%$ to $93.4 \%$ [24]. The Xisha area occurs within a tropical monsoon climate regime. The mean annual air temperature is $26.4^{\circ} \mathrm{C}$, with the lowest monthly temperature of $23.8^{\circ} \mathrm{C}$ in January and the highest monthly temperature of $29.4^{\circ} \mathrm{C}$ in June and July. From October to March, the area is affected by northeast monsoons with an average wind speed of 6-9 $\mathrm{m} \mathrm{s}^{-1}$ [22]. From May to August, the area is under the influence of SE-SW monsoons with an average wind speed of 5-6 $\mathrm{m} \mathrm{s}^{-1}$ [25].

Luhuitou Fringing Reef $\left(18.13^{\circ} \mathrm{N}, 109.29^{\circ} \mathrm{E}\right)$ is located at the southeast coast of Sanya, Hainan Island (Figure 1), northern SCS, and is a typical fringing reef. This reef is $\sim 3$ $\mathrm{km}$ long and has two typical biogeomorphologic units, reef flat and reef slope. The average width of its reef flat is $\sim 250$ $\mathrm{m}$, with the widest point reaching $450 \mathrm{~m}$. The present living coral cover is $\sim 5 \%$ at the reef flat and $\sim 12 \%$ on the reef slope. From 1960-2006, living coral cover in this fringing reef decreased from $\sim 85 \%$ to $\sim 12 \%$, but it still preserves relatively high biodiversity [26]. Luhuitou Fringing Reef experiences a tropical monsoon climatic system, dominated by northeast to east winds. From October to April, the area is affected by east and northeast monsoons. From May to September, the area is under the influence of south and southeast monsoons. The tides at Luhuitou Fringing Reef range from irregular diurnal-mixed tides to diurnal tides. The mean tidal level is $\sim 1.02 \mathrm{~m}$, and the mean tidal range is $\sim 0.79 \mathrm{~m}$, with the maximum reaching $\sim 1.89 \mathrm{~m}$. The mean annual sea surface temperature (SST) is $27^{\circ} \mathrm{C}$, and the lowest monthly SST is $23.8^{\circ} \mathrm{C}$ (varying from $20.5-24.7^{\circ} \mathrm{C}$ ). The highest monthly SST is $29.8^{\circ} \mathrm{C}$ (varying from $28.7-30.9^{\circ} \mathrm{C}$ ) [27].

\section{Methods}

Time-series measurements of air-sea $\mathrm{CO}_{2}$ exchanges were carried out at Yongxing Island in July 2008, at Yongshu Reef in June 2009, and at Luhuitou Fringing Reef in 


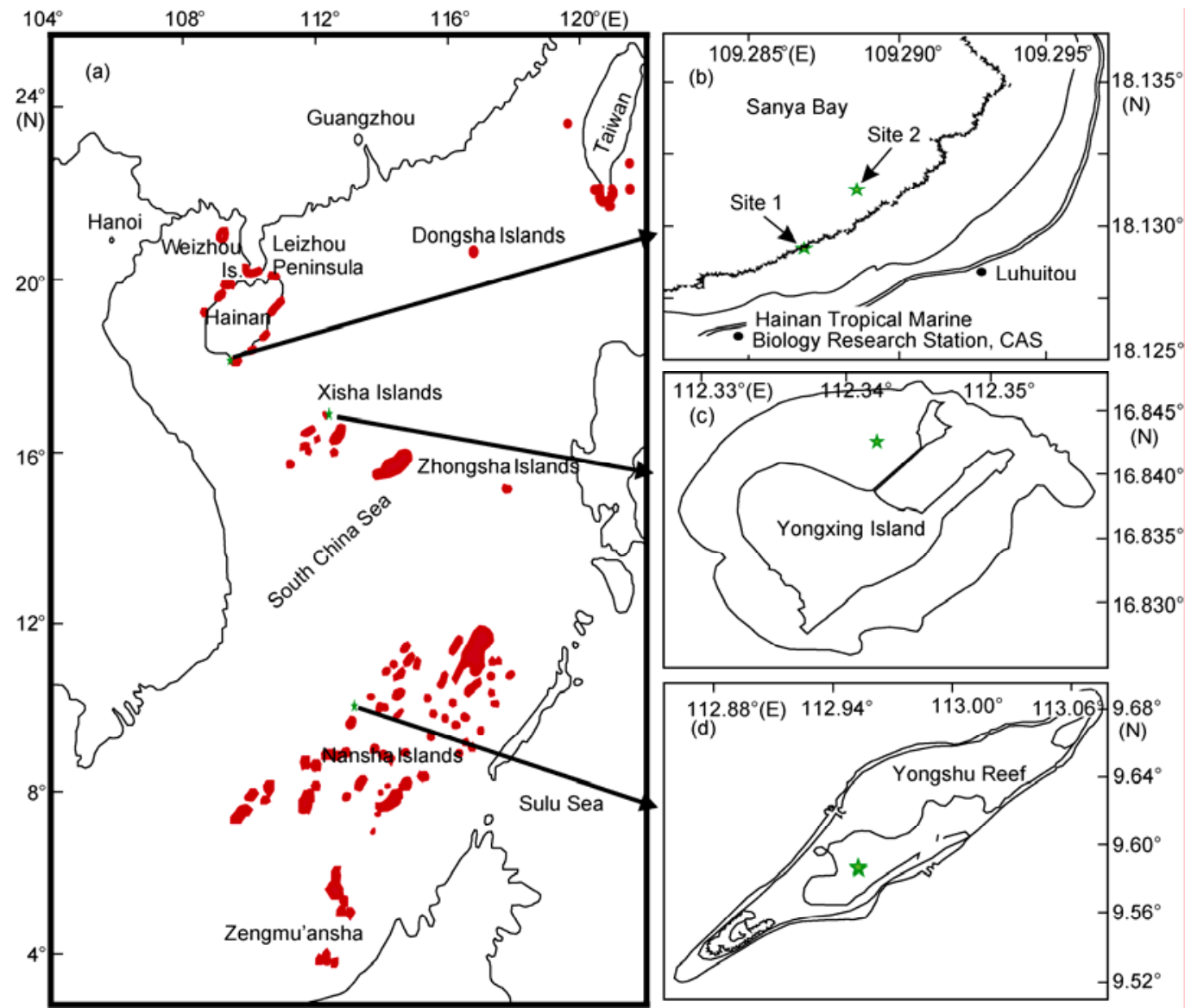

Figure 1 Location map of the investigated reefs in the SCS. Shaded areas represent the occurrence of coral reefs in the SCS [19]. 㐾 symbols in (b), (c) and (d) indicate investigation sites. "Site 1" in (b) is located on a reef flat at Luhuitou Fringing Reef, and "Site 2" is located outside the reef.

July-August 2009. Thus, all observations took place during summer. At Luhuitou Fringing Reef, measurements were taken from two locations: one inside (Site 1, Figure 1(b)), and one outside (Site 2, Figure 1(b)) the reef. Water depths at Site 1 and Site 2 were $\sim 1.1 \mathrm{~m}$ and $\sim 9 \mathrm{~m}$, respectively. The measurements were carried out hourly over six consecutive days at both sampling sites. At Yongxing Island, the observation site was located on the northern reef flat (Figure $1(\mathrm{c}))$. Measurements were taken every two hours over six consecutive days. At Yongshu Reef, the observation site was at a lagoon (Figure 1(d)), with hourly measurements made on two separate occasions: during a single day, then later on two consecutive days. Additionally, we also measured the air and sea $p \mathrm{CO}_{2}$ in the non-coral reef areas around the perimeter of the Nansha Islands (Figure 1(a)) during the South China Sea Institute of Oceanology (SCSIO) Nansha cruise in June 2009.

Atmospheric $p \mathrm{CO}_{2}$ was monitored continuously using a hand-held $\mathrm{CO}_{2}$ meter (GM70) made by the Vaisala Company, Finland. Sea surface temperature and sea surface salinity (SSS) were measured using a Yellow Spring Instrument meter (YSI6920V2), except at the reef flat of Yongxing Island, where SST and SSS were measured using an Ultrameter Model 4P (Myron L Company, USA). Water samples for $\mathrm{pH}$ and total alkalinity (TA) measurements were collected at water depths of $\sim 0.5 \mathrm{~m}$ (or $\sim 0.2 \mathrm{~m}$ at the reef flat during low tide). These samples were collected in $500 \mathrm{~mL}$ polyvinyl chloride (PVC) bottles, and then the samples were saturated with a $100 \mu \mathrm{L} \mathrm{HgCl}$ solution. The $\mathrm{pH}$ values were determined using a $\mathrm{pH}$ meter with a precision of $0.01 \mathrm{pH}$ units. The $\mathrm{pH}$ meter was calibrated against buffers of $\mathrm{pH} 6.86$ and 9.18 before every measurement. Following collection, the samples $(25 \mathrm{~mL})$ were immediately pre-filtered with a $0.45 \mu \mathrm{m}$ film and were then titrated in the field with $0.0006 \mathrm{~mol} / \mathrm{L} \mathrm{HCl}$ to calculate the TA. Seawater $p \mathrm{CO}_{2}$ was calculated $[12,19,28-31]$ using temperature, salinity, $\mathrm{pH}, \mathrm{TA}$, and constants from Mehrbach et al. [32] as refitted by Diskon and Millero [33].

The air-sea exchange flux of $\mathrm{CO}_{2}$ was determined from the following equation:

$$
F=k s\left(p \mathrm{CO}_{2 \mathrm{w}}-p \mathrm{CO}_{2 \mathrm{a}}\right),
$$

where $k$ is the gas transfer velocity, $s$ is the solubility of $\mathrm{CO}_{2}$ (calculated as a function of temperature and salinity), and $p \mathrm{CO}_{2 \mathrm{w}}$ and $p \mathrm{CO}_{2 \mathrm{a}}$ are the partial pressures of $\mathrm{CO}_{2}$ in seawater and air, respectively. Positive $F$ values indicated a flux of $\mathrm{CO}_{2}$ from the seawater to the atmosphere and a negative $F$ indicated a flux of $\mathrm{CO}_{2}$ from air to seawater. $k$ is 
commonly parameterized with wind speed $(u)$ and Schmidt number $(S c)$. We used the Wanninkhof [34] function of wind speed $(u)$ to calculate the value:

$$
K=0.31 u^{2}(S c / 660)^{-1 / 2},
$$

where $S c$ is the Schmidt number of $\mathrm{CO}_{2}$ in seawater; 660 is the $S c$ value in seawater $(S=35)$ at $20^{\circ} \mathrm{C} ; 0.31$ is a proportionality factor for short-term winds $\left(0-12 \mathrm{~m} \mathrm{~s}^{-1}\right)$. The mean wind speeds were obtained from NOAA (http://www.cdc. noaa.gov/data/).

\section{Results}

\subsection{Diurnal cycles of atmospheric and seawater $p \mathrm{CO}_{2}$ variations in coral reef areas}

Table 1 summarizes the mean SST, salinity, pH, TA, seawater $p \mathrm{CO}_{2}$ and atmospheric $p \mathrm{CO}_{2}$ at the study sites. Spatially, the seawater $p \mathrm{CO}_{2}$ values show large differences between sites. The mean seawater $p \mathrm{CO}_{2}$ at Yongshu Reef lagoon was the lowest amongst the three studied sites, and was slightly higher than the mean atmospheric $p \mathrm{CO}_{2}$. The diurnal amplitude of seawater $p \mathrm{CO}_{2}$ observed at Yongshu Reef lagoon also was much lower than that of the reef flats at Yongxing Island and Luhuitou Fringing Reef. The diurnal atmospheric $p \mathrm{CO}_{2}$ amplitudes at different coral reef areas were relatively small, and the mean daily atmospheric $p \mathrm{CO}_{2}$ values were similar among each of the coral reefs. Figure 2 shows that both atmospheric $p \mathrm{CO}_{2}$ and seawater $p \mathrm{CO}_{2}$ displayed clear diurnal cycles, with a decreasing trend during the daytime and an increasing trend at night. At the Yongxing Island reef flat, seawater $p \mathrm{CO}_{2}$ reached its minimum $\left(\sim 67 \mu \mathrm{mol} \mathrm{mol}^{-1}\right)$ at 17:00-19:00 and its maximum $\left(\sim 899 \mu \mathrm{mol} \mathrm{mol}{ }^{-1}\right)$ at 07:00-09:00. The diurnal seawater $p \mathrm{CO}_{2}$ amplitudes were as high as $420-619 \mu \mathrm{mol} \mathrm{mol}^{-1}$. At the reef flat of Luhuitou Fringing Reef, the seawater $p \mathrm{CO}_{2}$ reached its minimum $\left(\sim 340 \mu \mathrm{mol} \mathrm{mol}{ }^{-1}\right)$ at 16:00-18:00 and its maximum $\left(\sim 952 \mu \mathrm{mol} \mathrm{mol}{ }^{-1}\right)$ at 06:00-08:00. The diurnal seawater $p \mathrm{CO}_{2}$ amplitudes were 264-579 $\mu \mathrm{mol}$ $\mathrm{mol}^{-1}$ at Luhuitou reef flat and 386-492 $\mu \mathrm{mol} \mathrm{mol}{ }^{-1}$ just outside of the reef. At the Yongshu Reef lagoon, the diurnal cycle of seawater $p \mathrm{CO}_{2}$ variations did not appear to be as significant in comparison to the other sampled reefs, but the overall trend (i.e. decreasing during the daytime and increasing overnight) was still observed. The values reached a minimum at 22:00-24:00, and reached a maximum at 10:00-12:00. In comparison with that of Yongxing Island and Luhuitou Fringing Reef, seawater $p \mathrm{CO}_{2}$ peaks at Yongshu lagoon lagged by about $3-4 \mathrm{~h}$, which is possibly related to its low living coral cover and relatively deep water $(\sim 20 \mathrm{~m})$. As a result, mean seawater $p \mathrm{CO}_{2}$ and diurnal seawater $p \mathrm{CO}_{2}$ amplitudes both showed a clear decrease from within the reef area to outside of the reef. Since the diurnal atmospheric $p \mathrm{CO}_{2}$ amplitude was very small, its effect on air-sea $\mathrm{CO}_{2}$ exchange at the studied coral reefs was minor. The large diurnal amplitudes and associated seawater $p \mathrm{CO}_{2}$ variations indicate a significant exchange in air-sea $\mathrm{CO}_{2}$.

\subsection{Air-sea $\mathrm{CO}_{2}$ flux}

The air-sea $\mathrm{CO}_{2}$ fluxes (Figure 2) within different reef areas were calculated using equation 1 . At the Yongxing reef flat, air-sea $\mathrm{CO}_{2}$ flux ranged from -19.9-30.5 mmol $\mathrm{CO}_{2} \mathrm{~m}^{-2} \mathrm{~d}^{-1}$. From 13:00-23:00, its seawater $p \mathrm{CO}_{2}$ was generally lower than the atmospheric $p \mathrm{CO}_{2}$, and the average air-sea $\mathrm{CO}_{2}$ flux was $-5.1 \mathrm{mmol} \mathrm{CO}_{2} \mathrm{~m}^{-2} \mathrm{~d}^{-1}$. Its seawater $p \mathrm{CO}_{2}$ was larger than atmospheric $p \mathrm{CO}_{2}$, and for the remaining part of the day, the mean air-sea $\mathrm{CO}_{2}$ flux was $13.7 \mathrm{mmol} \mathrm{CO}_{2} \mathrm{~m}^{-2} \mathrm{~d}^{-1}$. At the reef flat in the Luhuitou Fringing Reef, the air-sea $\mathrm{CO}_{2}$ flux varied from -1.6-26.5 mmol $\mathrm{CO}_{2} \mathrm{~m}^{-2} \mathrm{~d}^{-1}$. Apart from a few hours at night, the seawater $p \mathrm{CO}_{2}$ was almost always larger than atmospheric $p \mathrm{CO}_{2}$ at Luhuitou. At the Yongshu Reef lagoon, the air-sea $\mathrm{CO}_{2}$ fluxes varied from $-2.3-2.7 \mathrm{mmol} \mathrm{CO}_{2} \mathrm{~m}^{-2} \mathrm{~d}^{-1}$. From 20:00-07:00, seawater $p \mathrm{CO}_{2}$ showed lower values with mean flux approaching 0 ; during the remaining portion of the day, the mean flux was $\sim 0.8 \mathrm{mmol} \mathrm{CO}_{2} \mathrm{~m}^{-2} \mathrm{~d}^{-1}$. The above data indicate great variations of air-sea fluxes between different reefs within the SCS. In general, coral reefs appeared to behave as sinks at night and as sources during the day. By integrating all the time-series $p \mathrm{CO}_{2}$ data, the flux was $\sim 4.7 \mathrm{mmol} \mathrm{CO}_{2} \mathrm{~m}^{-2}$ $\mathrm{d}^{-1}$ at the Yongxing reef flat, $\sim 0.4 \mathrm{mmol} \mathrm{CO}_{2} \mathrm{~m}^{-2} \mathrm{~d}^{-1}$ at the Yongshu Reef lagoon, and $\sim 9.8 \mathrm{mmol} \mathrm{CO}_{2} \mathrm{~m}^{-2} \mathrm{~d}^{-1}$ at the Luhuitou Fringing Reef flat.

\section{Discussion}

\subsection{Environmental controls of surface seawater $p \mathrm{CO}_{2}$}

In open ocean ecosystems, seawater $p \mathrm{CO}_{2}$ is controlled by a

Table 1 Summary of mean SST, SSS, pH, TA, seawater $p \mathrm{CO}_{2}$ and atmospheric $p \mathrm{CO}_{2}$ at the observation sites

\begin{tabular}{|c|c|c|c|c|c|c|c|}
\hline Reef site & $\begin{array}{l}\text { Mean depth } \\
(\mathrm{m})^{\mathrm{a})}\end{array}$ & $\operatorname{SST}\left({ }^{\circ} \mathrm{C}\right)$ & SSS $(\% o)$ & $\mathrm{pH}$ & $\mathrm{TA}\left(\mu \mathrm{mol} \mathrm{kg}{ }^{-1}\right)$ & $\begin{array}{l}\text { Seawater } p \mathrm{CO}_{2} \\
\left.(\mu \mathrm{mol} \mathrm{mol})^{-1}\right)^{\mathrm{b})}\end{array}$ & $\begin{array}{c}\text { Atmospheric } p \mathrm{CO}_{2} \\
\left.(\mu \mathrm{mol} \mathrm{mol})^{-1}\right)\end{array}$ \\
\hline Yongxing Island & 1.2 & $29.5 \pm 1.6$ & $32.6 \pm 0.4$ & $8.23 \pm 0.22$ & $2421 \pm 142$ & $456 \pm 249$ & $387 \pm 25$ \\
\hline Yongshu Reef & $\sim 30$ & $28.68 \pm 0.10$ & $33.07 \pm 0.19$ & $8.22 \pm 0.03$ & $2240 \pm 56$ & $395 \pm 25$ & $384 \pm 21$ \\
\hline Luhuitou Site 1 & 1.1 & $26.45 \pm 0.95$ & $33.45 \pm 0.30$ & $8.07 \pm 0.07$ & $2497 \pm 71$ & $610 \pm 112$ & $383 \pm 13$ \\
\hline Luhuitou Site 2 & 9 & $26.81 \pm 1.43$ & $33.27 \pm 0.40$ & $8.13 \pm 0.05$ & $2375 \pm 80$ & $506 \pm 81$ & $383 \pm 11$ \\
\hline
\end{tabular}

a) Mean depth corrected to relative mean sea level; b) seawater $p \mathrm{CO}_{2}$ was calculated from temperature, salinity, pH and TA. 

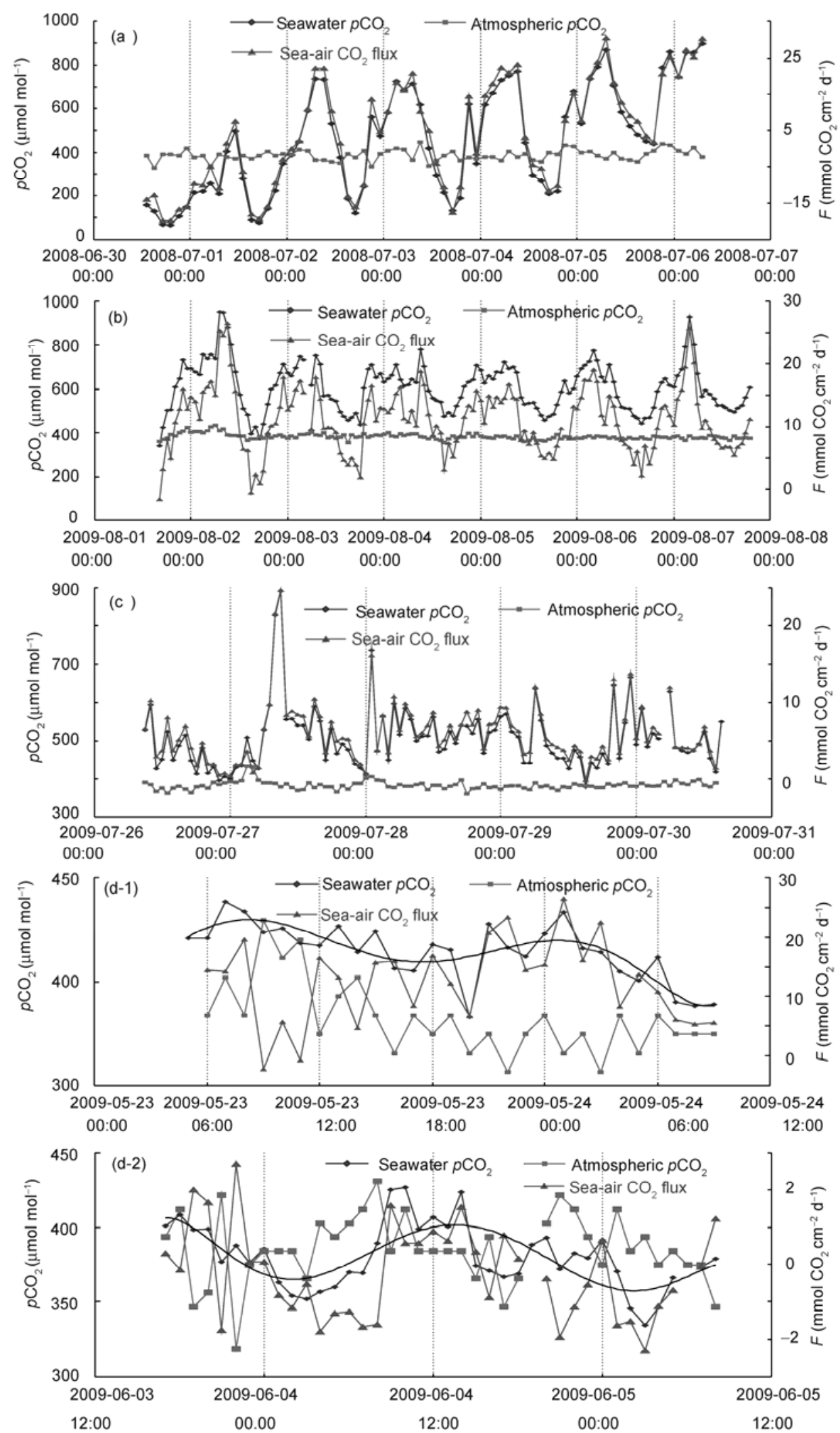

Figure 2 Diurnal variations of atmospheric $p \mathrm{CO}_{2}$, seawater $p \mathrm{CO}_{2}$ and air-sea $\mathrm{CO}_{2}$ flux in the studied coral reef areas. (a) Reef flat at Yongxing Island; (b) reef flat at Luhuitou Fringing Reef; (c) outside of Luhuitou Fringing Reef; (d-1) and (d-2) Lagoon at Yongshu Reef. 2009-06-30 00:00: midnight (00:00) of June 30, 2009. 
variety of environmental conditions, including SST, hydrodynamics, and biological activities [20]. In order to eliminate SST effects on observed $p \mathrm{CO}_{2}$, the measured $p \mathrm{CO}_{2}$ values were normalized to the mean SST during the observation period, using the following equation:

$$
\mathrm{NpCO}_{2}=\left(\text { in situ } p \mathrm{CO}_{2}\right) \times \exp \left[0.0423\left(T_{\text {mean }}-T_{\text {in situ }}\right)\right] \text {, }
$$

where $T$ is the SST in degrees Celsius, and the subscripts "mean" and "in situ" indicate the averaged and the observed values, respectively $[20,35,36]$. The calculated $\mathrm{NpCO}_{2}$ values show that similar variations in measured $p \mathrm{CO}_{2}$ occurred in all three study areas, suggesting that local SST variations over the observation period did not affect observed diurnal cycles or overall trends of seawater $p \mathrm{CO}_{2}$. To examine the contribution of SST on surface seawater $p \mathrm{CO}_{2}$, we computed the offset between $N p \mathrm{CO}_{2}$ and measured $p \mathrm{CO}_{2}$ (Table $2)$, herein defined as $\delta p \mathrm{CO}_{2}\left(\delta p \mathrm{CO}_{2}=\mid\right.$ measured $p \mathrm{CO}_{2}-$ $\left.N p \mathrm{CO}_{2} \mid\right)$. The mean $\delta p \mathrm{CO}_{2}$ values at the reef flats of Luhuitou Fringing Reef and Yongxing Island were greater than that at the Yongshu Reef lagoon. We defined the largest seawater $p \mathrm{CO}_{2}$ variation amplitude during the observation period as $\Delta p \mathrm{CO}_{2}$, and then calculated the ratio (= $\delta p \mathrm{CO}_{2} / \Delta p \mathrm{CO}_{2}$ ) between $\delta p \mathrm{CO}_{2}$ and $\Delta p \mathrm{CO}_{2}$ (Table 2). The results (Table 2) show that SST variation had a contribution of only $6.17 \%$ of the observed seawater $p \mathrm{CO}_{2}$ at the Luhuitou Fringing Reef, $4.34 \%$ at the Yongxing Island, and $2.66 \%$ at the Yongshu Reef. Thus, SST did not appear to be a major factor controlling diurnal variations of seawater $p \mathrm{CO}_{2}$. The apparent minor variation in the contribution of SST to seawater $p \mathrm{CO}_{2}$ across the three studied reefs is possibly the result of local SST amplitude differences.

Hydrodynamic processes, such as tides, can affect the coral reef carbonate system by driving seawater exchange between the reef area and the surrounding ocean. The seawater exchange rate between the outer and inner reef, as well as water depth, can impact the observed seawater $p \mathrm{CO}_{2}$. For example, Table 1 demonstrates that the seawater $p \mathrm{CO}_{2}$ value decreased between the shallow-water reef flat to the deep-water site just outside of the main reef at Luhuitou. Dai et al. [20] proposed that the daily seawater mass exchanged between the inner and outer sections of a given reef may be roughly estimated by determining the ratio of the average tidal range versus the average water depth. Given that the average water depths were $\sim 10 \mathrm{~m}$ for the reef around Yongxing Island, $\sim 4 \mathrm{~m}$ for the Luhuitou Fringe Reef, and $\sim 25 \mathrm{~m}$ for the Yongshu Reef lagoon, and their average tidal ranges were $\sim 1 \mathrm{~m}, \sim 0.8 \mathrm{~m}$, and $\sim 1.2 \mathrm{~m}$, re- spectively, the estimated daily exchange amount of water mass between the inside and outside of the reefs were $\sim 10 \%, \sim 20 \%$, and $\sim 4.8 \%$ of the total water mass in the reefs, respectively. This suggests that tide-dominated hydrodynamic processes are not the major factor controlling the observed $p \mathrm{CO}_{2}$ diurnal variations in the studied reefs. This can be further supported by the fact that there does not appear to be a correlation between tidal height and seawater $p \mathrm{CO}_{2}$.

Biological metabolism directly controls seawater $p \mathrm{CO}_{2}$ variations. During the night, respiration and calcification by coral reef organisms releases $\mathrm{CO}_{2}$, which increases seawater $p \mathrm{CO}_{2}$. Conversely, during the daytime, the $\mathrm{CO}_{2}$ that is fixed by photosynthesis is greater than that released from respiration and calcification, and therefore, seawater $p \mathrm{CO}_{2}$ decreases. The observed diurnal cycles (i.e. surface seawater $p \mathrm{CO}_{2}$ increasing at night and decreasing during the daytime) are significantly correlated with reef metabolic processes, suggesting that biological metabolism dominates seawater $p \mathrm{CO}_{2}$ variations in coral reef waters [17,20,37].

Previous studies have indicated that seawater $\mathrm{CO}_{2}$ chemical equilibrium determines the $\mathrm{CO}_{2}$ absorption capacity of coral reefs [38]. Based on previous work [9], for each mole of $\mathrm{CaCO}_{3}$ precipitated, seawater TA and DIC decrease by $2 \mathrm{eq}$ and $1 \mathrm{~mol}$. Thus, the slope ( $\triangle \mathrm{TA} / \Delta \mathrm{DIC}$ ) equals $2 / 1$ if only calcification is considered. The slope will be nearly 0 if only photosynthesis is considered, as photosynthesis has no effect on TA. Assuming a given calcification: photosynthesis ratio of 1 unit inorganic to $x$ units organic carbon, the slope $(\Delta \mathrm{TA} / \Delta \mathrm{DIC})$ must equal $2 /(1+x)$, and hence $x=$ (2/slope)-1. Figure 3 shows the linear regression lines of observed seawater TA and DIC of the coral reefs in this study. The calculated slope, $T,(\Delta \mathrm{TA} / \Delta \mathrm{DIC})$, was $\sim 0.47$ at the Yongxing reef flat, $\sim 0.77$ at the Luhuitou reef flat, and $\sim 1.05(=(1.08+1.01) / 2)$ at the Yongshu atoll lagoon. The ratio of inorganic to organic production was $\sim 1: 3.3$ at Yongxing Island, $\sim 1: 1.6$ at the Luhuitou reef flat, and $\sim 1: 0.9$ at the Yongshu Reef lagoon. The ratio at the Luhuitou reef flat $(\sim 1: 1.6)$ was larger than that at the Yongxing reef flat $(\sim 1: 3.3)$, which suggests that $\mathrm{CaCO}_{3}$ production was more prominent at Luhuitou. Due to calcification causing $\mathrm{CO}_{2}$ release, the Luhuitou Fringing Reef hypothetically should be a more significant source of atmospheric $\mathrm{CO}_{2}$ than at Yongxing Island. Indeed, this is supported by the demonstrated air-sea $\mathrm{CO}_{2}$ fluxes in section 3.2. Though Yongshu lagoon had the highest ratio, its air-sea $\mathrm{CO}_{2}$ flux

Table 2 Contribution of SST to seawater $p \mathrm{CO}_{2}$ variability

\begin{tabular}{|c|c|c|c|c|c|c|c|}
\hline \multirow{2}{*}{ Reef site } & \multicolumn{3}{|c|}{$\delta p \mathrm{CO}_{2}\left(\mu \mathrm{mol} \mathrm{mol}{ }^{-1}\right)$} & \multirow{2}{*}{$\Delta p \mathrm{CO}_{2}\left(\mu \mathrm{mol} \mathrm{mol}{ }^{-1}\right)$} & \multicolumn{3}{|c|}{$\delta p \mathrm{CO}_{2} / \Delta p \mathrm{CO}_{2}(\%)$} \\
\hline & Minimum & Maximum & Mean & & Minimum & Maximum & Mean \\
\hline Luhuitou Fringing Reef & 0.0 & 78.3 & 25.6 & 415 & 0.00 & 18.86 & 6.17 \\
\hline Yongshu Reef & 0.0 & 8.8 & 1.6 & 60 & 0.00 & 14.71 & 2.66 \\
\hline
\end{tabular}


was the lowest $\left(\sim 0.4 \mathrm{mmol} \mathrm{CO}_{2} \mathrm{~m}^{-2} \mathrm{~d}^{-1}\right)$, which may be a result of the buffering effect of its deeper waters. A ratio of $1: 14$ (inorganic to organic carbon production) was observed in the SCS basin area by Cao et al. [37] in 2005. This ratio is much lower than that in the coral reef areas of the SCS. This information suggests that the inorganic carbon metabolism in coral reefs of the SCS plays a significant role in coral reef carbon cycles. This may explain the observed large diurnal variations of seawater $p \mathrm{CO}_{2}$.

\section{2 $\mathrm{pCO}_{2}$ difference between inner and outer coral reef areas}

The net effect of air-sea $\mathrm{CO}_{2}$ fluxes for a given reef can be masked if the oceanic water is already out of equilibrium with atmospheric $\mathrm{CO}_{2}$ before entering the reef system $[7,39,40]$. Thus, the seawater exchange between an atoll lagoon and outer oceanic water can sometimes make it difficult to fully understand the coral reef carbon cycle system. In order to identify the net effect of reef systems on the air-sea $\mathrm{CO}_{2}$ exchange, we first need to compare seawater $p \mathrm{CO}_{2}$ between the inside and the outside of the studied coral reefs [40]. Following a previous study [39], we defined the difference in $p \mathrm{CO}_{2}$ between the inside and outside coral reef area $\left(\delta p \mathrm{CO}_{2}\right)$ as

$$
\delta p \mathrm{CO}_{2}=p \mathrm{CO}_{2 \mathrm{~L}}-p \mathrm{CO}_{2 \mathrm{O}},
$$

where $p \mathrm{CO}_{2 \mathrm{~L}}$ and $p \mathrm{CO}_{2 \mathrm{O}}$ are the partial pressure of carbon dioxide in the atoll lagoon water, and the oceanic water outside the coral reef, respectively. If the mean $p \mathrm{CO}_{2}$ of lagoon water is higher than that of oceanic water (i.e. $\delta p \mathrm{CO}_{2}>0$ ), the coral reef is likely to be a source of atmospheric $\mathrm{CO}_{2}$. Conversely, if the mean $p \mathrm{CO}_{2}$ of the lagoon water is lower than that of oceanic water (i.e. $\delta p \mathrm{CO}_{2}<0$ ), the coral reef more likely acts as a sink of atmospheric $\mathrm{CO}_{2}$. Considering that tidal mixing can influence seawater $p \mathrm{CO}_{2}$ as far as 4 $\mathrm{km}$ from a coral reef [40], we used the averaged seawater $p \mathrm{CO}_{2}$ data $\left(370 \mu \mathrm{mol} \mathrm{mol}{ }^{-1}\right)$ observed from 18 stations located up to $4 \mathrm{~km}$ away from Yongshu Reef to represent oceanic water $p \mathrm{CO}_{2}$ of the region. We then calculated the seawater $p \mathrm{CO}_{2}$ difference $\left(\delta p \mathrm{CO}_{2}\right)$ between the inner and outer Yongshu Reef as $25 \mu \mathrm{mol} \mathrm{mol}{ }^{-1}$. The results suggest that Yongshu Reef lagoon is a significant source of atmospheric $\mathrm{CO}_{2}$. The observed seawater $p \mathrm{CO}_{2}$ at stations located $4 \mathrm{~km}$ away from Yongxing Island and Luhuitou Fringing Reef were 379 and $381 \mu \mathrm{mol} \mathrm{mol}{ }^{-1}$, respectively. The calculated $\delta p \mathrm{CO}_{2}$ for the reef flats at Yongxing Island and Luhuitou Fringing Reef were 77 and $229 \mu \mathrm{mol} \mathrm{mol}{ }^{-1}$, respectively. Even at Site 2 of the Luhuitou Fringing Reef, the seawater $p \mathrm{CO}_{2}$ was $125 \mu \mathrm{mol} \mathrm{mol}{ }^{-1}$ higher than that of stations $4 \mathrm{~km}$ away. Collectively, the above calculations of $\delta p \mathrm{CO}_{2}$ suggest that the three studied coral reefs are a source of atmospheric $\mathrm{CO}_{2}$.

\subsection{Coral reefs of the SCS act as sources of atmos- pheric $\mathrm{CO}_{2}$}

Air-sea $\mathrm{CO}_{2}$ flux values may be used to differentiate coral reefs that act as either sinks or sources of atmospheric $\mathrm{CO}_{2}$ [6-18]. Positive values typically characterize coral reefs as a source of atmospheric $\mathrm{CO}_{2}$, whilst negative values may
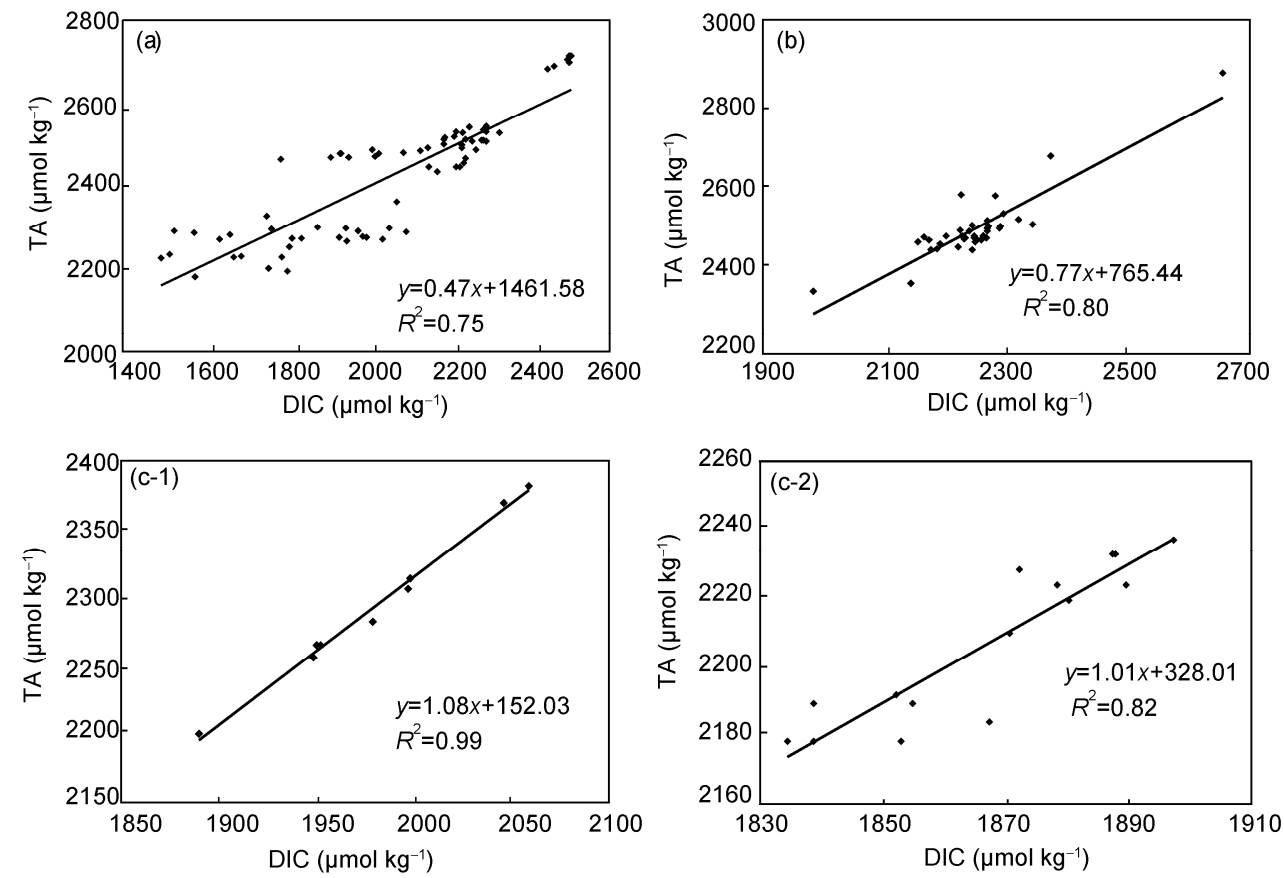

Figure 3 Plots of TA vs. DIC in the studied coral reefs. (a) Reef flat at Yongxing Island; (b) reef flat at Luhuitou Fringing Reef; (c-1) Yongshu Reef lagoon during 2009-05-23 to 2009-05-24; and (c-2) Yongshu Reef lagoon during 2009-06-03 to 2009-06-05. 
identify coral reefs that act as a sink of atmospheric $\mathrm{CO}_{2}$. Based on this principle and the calculated air-sea $\mathrm{CO}_{2}$ flux values (Figure 2) for this study, Luhuitou Fringing Reef appears to be a strong source of atmospheric $\mathrm{CO}_{2}$. Yongxing Island most likely acts as a sink for atmospheric $\mathrm{CO}_{2}$ between 13:00 and 23:00, but as a source at all other times during the $24 \mathrm{~h}$ cycle. Yongshu Reef appears to be a source of atmospheric $\mathrm{CO}_{2}$ from 07:00 to 20:00, but acts as a sink for the rest of the day. In general, coral reefs in the SCS appear to absorb atmospheric $\mathrm{CO}_{2}$ at night and release $\mathrm{CO}_{2}$ to the atmosphere during the daytime. The averaged data show that each of the three studied reefs in the SCS act as a source of atmospheric $\mathrm{CO}_{2}$ in summer. Due to seasonal variations within the physical and chemical environment, as well as the community metabolism in the coral reefs, air-sea $\mathrm{CO}_{2}$ fluxes may differ between seasons. For example, an air-sea $\mathrm{CO}_{2}$ flux value of $\sim 1.48 \mathrm{mmol} \mathrm{CO}_{2} \mathrm{~m}^{-2} \mathrm{~d}^{-1}$ was observed during spring at the reef flat at Yongxing Island, thus indicating that the reef is a minor source of atmospheric $\mathrm{CO}_{2}$ [20]. Additional studies over different seasons are necessary to achieve a comprehensive evaluation of the actual contribution of atmospheric $\mathrm{CO}_{2}$ by SCS coral reefs.

\section{Conclusions}

We observed time-series variations of air-sea $\mathrm{CO}_{2}$ exchange at Yongshu Reef (atoll) of Nansha Islands, southern SCS; Yongxing Island (platform reef), Xisha Islands, north-central SCS; and at Luhuitou Fringing Reef at Sanya of Hainan Island, northern SCS, during the summers of 2008 and 2009. We concluded that:

(1) Both air and surface seawater $p \mathrm{CO}_{2}$ of the three studied coral reef areas showed significant diurnal cycling, with a decreasing phase during the daytime and an increasing phase during the night. This cyclic variation was particularly clear in areas that had high proportions of coral cover, such as the reef flats of Luhuitou Fringing Reef and Yongxing Island.

(2) Air $p \mathrm{CO}_{2}$ in each of the investigated areas showed a small-range of diurnal variations, whilst large-range diurnal variations were observed in seawater $p \mathrm{CO}_{2}$ from all areas. The diurnal variation amplitude of seawater $p \mathrm{CO}_{2}$ was $\sim 70$ $\mu \mathrm{mol} \mathrm{mol}{ }^{-1}$ at the Yongshu Reef lagoon; 420-619 $\mu \mathrm{mol}$ $\mathrm{mol}^{-1}$ at the Yongxing Island reef flat; 264-579 $\mu \mathrm{mol} \mathrm{mol}{ }^{-1}$ on the reef flat of Luhuitou Fringing Reef; and 324-492 $\mu \mathrm{mol}$ $\mathrm{mol}^{-1}$ at an adjacent area just outside of this fringing reef.

(3) Within spatial scales, there were large differences in air-sea $\mathrm{CO}_{2}$ flux from site to site (e.g. $\sim 0.4 \mathrm{mmol} \mathrm{CO}_{2} \mathrm{~m}^{-2}$ $\mathrm{d}^{-1}$ at Yongshu Reef; $4.7 \mathrm{mmol} \mathrm{CO}_{2} \mathrm{~m}^{-2} \mathrm{~d}^{-1}$ at Yongxing Island; and $\sim 9.8 \mathrm{mmol} \mathrm{CO}_{2} \mathrm{~m}^{-2} \mathrm{~d}^{-1}$ at Luhuitou Fringing Reef). In general, the positive values suggest that coral reef ecosystems of the SCS appear to be net sources of $\mathrm{CO}_{2}$ to the atmosphere, at least during the observed summer season.
(4) Diurnal variations of surface seawater $p \mathrm{CO}_{2}$ in the shallow water reef flat was mainly controlled by biological metabolism. However, diurnal variations of surface seawater $p \mathrm{CO}_{2}$ of the deeper water lagoons and outer reef area was controlled by both biological metabolism and hydrodynamic processes. In comparison with the open oceanic realm, inorganic metabolism plays a far more significant role in coral reef ecosystems by influencing seawater $p \mathrm{CO}_{2}$ variations.

The authors thank the Hainan Xisha Islands-Zhongsha Islands \& Nansha Islands working committee, Hainan Tropical Marine Biology Research Station of the Chinese Academy of Sciences, and the Management Bureau of Sanya Coral Reef National Natural Reserves for providing support with the fieldwork. Dr. Gilbert J Price from the University of Queensland is greatly thanked for improving the language of the manuscript. This work was supported by the National Natural Science Foundation of China (40830852 and 41025007), the Chinese Ministry of Science and Technology Special Scheme (2007CB815905 and 2006BAB19B03), and an Australian Research Council Project (DP0773081).

1 Yan H Q, Yu K F, Tan Y H. Recent development in the research of carbon cycle in coral reef ecosystem (in Chinese). Acta Ecol Sin, 2009, 29: 6207-6215

2 Berger W H. Increase of carbon dioxide in the atmosphere during deglaciation: The coral reef hypothesis. Naturwissenschaften, 1982, 69: $87-88$

3 Opdyke B N, Walker J C. Return of the coral reef hypothesis: Basin to shelf partitioning of $\mathrm{CaCO}_{3}$ and its effect on atmospheric $\mathrm{CO}_{2}$. Geology, 1992, 20: 733-736

4 Mylroie J E, Opdyke B N, Walker J C. Return of the coral reef hypothesis: Basin to shelf partitioning of $\mathrm{CaCO}_{3}$ and its effect on atmospheric $\mathrm{CO}_{2}$ : Comment and Reply. Geology, 1993, 21: 475-476

5 Crossland C J, Hatcher B G, Smithe S V. Role of coral reefs in global ocean production. Coral Reefs, 1991, 10: 55-64

6 Suzuki A, Kawahata $\mathrm{H}$. Reef water $\mathrm{CO}_{2}$ system and carbon production of coral reefs: Topographic control of system-level performance. In: Shiyomi M, Kawahata H, Koizumi H, et al., eds. Global Environmental Change in the Ocean and on Land. Tokyo: Terraphub, 2004. 229-248

7 Kawahata H, Suzuki A, Goto K. Coral reef ecosystems as a source of atmospheric $\mathrm{CO}_{2}$ : Evidence from $p \mathrm{CO}_{2}$ measurements of surface waters. Coral Reefs, 1997, 16: 261-266

8 Ware J R, Smith S V, Reaka-Kudla M L. Coral reefs: Sources or sinks of atmospheric $\mathrm{CO}_{2}$. Coral Reefs, 1991, 11: 127-130

9 Gattuso J P, Frankignoulle M, Smith S V. Measurement of community metabolism and significance in the coral reef $\mathrm{CO}_{2}$ source-sink debate. Proc Natl Acad Sci USA, 1999, 96: 13017-13022

10 Gattuso J P, Pichon M, Jaubert J, et al. Primary production, calcification and air-sea $\mathrm{CO}_{2}$ fluxes in coral reefs: Organism, ecosystem and global scales. Bull Inst Oceanogr, 1996, 14 : 39-46

11 Kawahata H, Yukino I, Suzuki A. Terrestrial influences on the Shiraho fringing reef, Ishigaki Island, Japan: High carbon input relative to phosphate. Coral Reefs, 2000, 19: 172-178

12 Fagan K E, Mackenzie F T. Air-sea $\mathrm{CO}_{2}$ exchange in a subtropical estuarine-Coral reef system, Kaneohe Bay, Oahu, Hawaii. Mar Chem, 2007, doi:10.1016/j.marchem. 2007. 01.016

13 Frankignoulle M, Gattuso J P, Biondo R, et al. Carbon fluxes in coral reefs. II. Eulerian study of inorganic carbon dynamics and measurement of air-sea $\mathrm{CO}_{2}$ exchanges. Mar Ecol Prog Ser, 1996, 145: 123-132

14 Gattuso J P, Pichon M, Delesalle B, et al. Community metabolism and air-sea $\mathrm{CO}_{2}$ fluxes in a coral reef ecosystem (Moorea, French Polynesia). Mar Ecol Prog Ser, 1993, 96: 259-267

15 Kawahata H, Suzuki A, Goto K. Coral reefs as source of atmospheric $\mathrm{CO}_{2}$-spatial distribution of $p \mathrm{CO}_{2}$ in Majuro atoll. Geochem J, 1999, 
33: 295-303

16 Kawahata H, Suzuki A, Ayukai T, et al. Distribution of the fugacity of carbon dioxide in the surface seawater of the Great Barrier Reef. Mar Chem, 2000, 72: 257-272

17 Kayanne H, Suzuka A, Saito H. Diurnal changes in the partial pressure of carbon dioxide in coral reef water. Science, 1995, 269: 214-216

18 Suzuki A. Combined effects of photosynthesis and calcification on the partial pressure of carbon dioxide in the seawater. J Oceanogr, 1998, 54: 1-7

19 Wang P X, Li Q Y. The South China Sea: Paleoceanography and Sedimentology. Berlin/Heidelberg: Springer-Verlag, 2009. 229-243

20 Dai M H, Lu Z M, Zhai W D, et al. Diurnal variations of surface seawater $p \mathrm{CO}_{2}$ in contrasting coastal environments. Limnol Oceanogr, 2009, 54: 735-745

21 Yu K F, Zhao J X, Shi Q, et al. New insights into biologicalgeomorphological-sedimentary zones and environment records at the southwest reef bracelet of Yongshu Reef, Nansha Islands (in Chinese). Mar Geol Quat Geol, 2003, 23: 1-7

22 Yu K F, Zhao J X, Collerson K D, et al. Storm cycles in the last millennium recorded in Yongshu Reef, southern South China Sea. Palaeogeogr Palaeoclimat Palaeoecol, 2004, 210: 89-100

23 Yu K F, Song C J, Zhao H T. The characters of geomorphology and modern sediments of Yongxing Island, Xisha Islands (in Chinese). Trop Ocean, 1995, 14: 24-31

24 Li Y H, Huang X P, Yue W Z, et al. Ecological study on coral reef and intertidal benthos around Yongxing Island, South China Sea (in Chinese). Oceanol Limnol Sin, 2004, 35: 176-182

25 Nie B F, Chen T G, Liang M T, et al. The Relationship Between Reef Coral and Environmental Changes of Nansha Islands and Adjacent Regions (in Chinese). Beijing: Science Press, 1997. 20-21

26 Zhao M X, Yu K F, Zhang Q M, et al. Long-term dynamics of coral cover in Luhuitou Fring Reef, Sanya (in Chinese). Oceanol Limnol Sin, 2010, 41: 440-447

27 Li S, Yu K F, Shi Q, et al. Interspecies and spatial diversity in the symbiotic zooxanthellae density in corals from northern South China Sea and its relationship to coral reef bleaching. Chinese Sci Bull, 2007, 52: 2655-2622
28 Lewis E, Wallace D. Program developed for $\mathrm{CO}_{2}$ system calculations. Oak Ridge Natl Lab, Carbon Dioxide Info Anal Cent, ORNL/CDIAC-105 US Dept of Energy. 1998

29 Watanabe A, Kayanne $\mathrm{H}$, Hata $\mathrm{H}$, et al. Analysis of the seawater $\mathrm{CO}_{2}$ system in the barrier reef-lagoon system of Palau using total alkalinitydissolved inorganic carbon diagrams. Limnol Oceanogr, 2006, 51: 1614 1628

30 McGillis W R, Wanninkhof R. Aqueous $\mathrm{CO}_{2}$ gradients for air-sea flux estimates. Mar Chem, 2006, 98: 100-108

31 Kraines S, Suzuki Y, Omori T, et al. Carbonate dynamics of the coral reef system at Bora Bay, Miyako Island. Mar Ecol Prog Ser, 1997, 156: $1-16$

32 Mehrbach C, Cullberson C H, Hawley J R, et al. Measurement of the apparent dissociation constants of carbonic acid in seawater at atmospheric pressure. Limnol Oceanogr, 1973, 18: 897-907

33 Dickson A G, Millero F J. A comparison of the equilibrium constants of the dissociation of carbonic acid in seawater media. Deep-Sea Res A, 1987, 34: 1733-1743

34 Wanninkhof R. Relationship between wind speed and gas exchange over the ocean. J Geophys Res, 1992, 97: 7373-7382

35 Takahashi T, Sutherland S C, Sweeney C, et al. Global sea-air $\mathrm{CO}_{2}$ flux based on climatological surface ocean $p \mathrm{CO}_{2}$, and seasonal biological and temperature effects. Deep-Sea Res II, 2002, 49: 1601-1622

36 Bates N R, Samules L, Merlivant L. Biogeochemical and physical factors influencing seawater $f \mathrm{CO}_{2}$ and air-sea $\mathrm{CO}_{2}$ exchange on Bermuda coral reef. Limnol Oceanogr, 2001, 46: 838-846

37 Cao Z M, Dai M H, Lu Z M, et al. $\mathrm{CaCO}_{3}$ to organic carbon ratio in the South China Sea. Adv Geosci, 2007, 6: 109-125

38 Ohde S. Calcium carbonate production and carbon dioxide flux on a coral reef, Okinawa. In: Biogeochemical Processes and Ocean Flux in the Western Pacific, 1995. 93-98

39 Suzuki A, Kawahata H. Carbon budget of coral reef systems: An overview of observations in fringing reefs, barrier reefs and atolls in the Indo-pacific regions. Tellus, 2003, 55: 428-444

40 Suzuki A, Kawahata H. Partial pressure of carbon dioxide in coral reef lagoon waters: comparative study of atolls and barrier reefs in the indo-pacific oceans. J Oceanogr, 1999, 55: 731-745

Open Access This article is distributed under the terms of the Creative Commons Attribution License which permits any use, distribution, and reproduction in any medium, provided the original author(s) and source are credited. 